\title{
EFFECT OF COMPACTION ON MICROBIAL ACTIVITY AND CARBON AND NITROGEN TRANSFORMATIONS IN TWO OXISOLS WITH DIFFERENT MINERALOGY(1)
}

\author{
Sérgio Ricardo Silva ${ }^{(2)}$, Ivo Ribeiro da Silva ${ }^{(3)}$, Nairam Félix de \\ Barros $^{(3)}$ \& Eduardo de Sá Mendonça ${ }^{(4)}$
}

\begin{abstract}
SUMMARY
The use of machinery in agricultural and forest management activities frequently increases soil compaction, resulting in greater soil density and microporosity, which in turn reduces hydraulic conductivity and $\mathrm{O}_{2}$ and $\mathrm{CO}_{2}$ diffusion rates, among other negative effects. Thus, soil compaction has the potential to affect soil microbial activity and the processes involved in organic matter decomposition and nutrient cycling. This study was carried out under controlled conditions to evaluate the effect of soil compaction on microbial activity and carbon (C) and nitrogen $(\mathrm{N})$ mineralization. Two Oxisols with different mineralogy were utilized: a clayey oxidic-gibbsitic Typic Acrustox and a clayey kaolinitic Xantic Haplustox (Latossolo Vermelho-Amarelo ácrico - LVA, and Latossolo Amarelo distrófico - LA, respectively, in the Brazil Soil Classification System). Eight treatments (compaction levels) were assessed for each soil type in a complete block design, with six repetitions. The experimental unit consisted of PVC rings (height $6 \mathrm{~cm}$, internal diameter $4.55 \mathrm{~cm}$, volume $97.6 \mathrm{~cm}^{3}$ ). The PVC rings were filled with enough soil mass to reach a final density of 1.05 and $1.10 \mathrm{~kg} \mathrm{dm}^{-3}$, respectively, in the LVA and LA. Then the soil samples were wetted $\left(0.20 \mathrm{~kg} \mathrm{~kg}^{-1}=\right.$ $80 \%$ of field capacity) and compacted by a hydraulic press at pressures of 0,60 , $120,240,360,540,720$ and $900 \mathrm{kPa}$. After soil compression the new bulk density was calculated according to the new volume occupied by the soil. Subsequently each PVC ring was placed within a $1 \mathrm{~L}$ plastic pot which was then tightly closed. The soils were incubated under aerobic conditions for 35 days and the basal respiration rate $\left(\mathrm{CO}_{2}-\mathrm{C}\right.$ production) was estimated in the last two weeks. After the incubation period, the following soil chemical and microbiological properties were
\end{abstract}

\footnotetext{
(1) Part of the Doctoral Thesis of first author, presented to Graduate Program in Soil and Plant Nutrition, Federal University of Viçosa (UFV). Scientific work presented at XXVI Reunião Brasileira de Fertilidade do Solo e Nutrição de Plantas, in Lajes (SC), in 2004. Study funded by CAPES. Received for publication in July 6, 2009 and approved in May 6, 2011.

(2) Forest Technology Department, Veracel Celulose S.A., PO Box 21, Zip Code 45820-970, Eunápolis (BA). E-mail: sergio.silva@veracel.com.br

(3) Professor, Soil Science Departament, Federal University of Viçosa (UFV), Viçosa (MG). E-mails: ivosilva@ufv.br; nfbarros@ufv.br

(4) Professor, Plant Production Department, Federal University of Espírito Santo (UFES), Alegre (ES). E-mail: esmjplia@gmail.com
} 
detremined: soil microbial biomass $\mathrm{C}\left(\mathrm{C}_{\mathrm{MIC}}\right)$, total soil organic $\mathrm{C}$ (TOC), total $\mathrm{N}$, and mineral $\mathrm{N}\left(\mathrm{NH}_{4}{ }^{+}-\mathrm{N}\right.$ and $\left.\mathrm{NO}_{3}{ }^{-}-\mathrm{N}\right)$. After that, mineral $\mathrm{N}$, organic $\mathrm{N}$ and the rate of net $\mathrm{N}$ mineralization was calculated. Soil compaction increased $\mathrm{NH}_{4}{ }^{+}-\mathrm{N}$ and net $\mathrm{N}$ mineralization in both, LVA and $\mathrm{LA}$, and $\mathrm{NO}_{3}^{-}-\mathrm{N}$ in the LVA; diminished the rate of TOC loss in both soils and the concentration of $\mathrm{NO}_{3}^{-}-\mathrm{N}$ in the $\mathrm{LA}$ and $\mathrm{CO}_{2}-\mathrm{C}$ in the LVA. It also decreased the $\mathrm{C}_{\text {MIC }}$ at higher compaction levels in the LA. Thus, soil compaction decreases the TOC turnover probably due to increased physical protection of soil organic matter and lower aerobic microbial activity. Therefore, it is possible to conclude that under controlled conditions, the oxidic-gibbsitic Oxisol (LVA) was more susceptible to the effects of high compaction than the kaolinitic (LA) as far as organic matter cycling is concerned; and compaction pressures above $540 \mathrm{kPa}$ reduced the total and organic nitrogen in the kaolinitic soil (LA), which was attributed to gaseous $\mathrm{N}$ losses.

Index terms: soil bulk density, carbon mineralization, net $\mathrm{N}$ mineralization, microbial biomass carbon.

\title{
RESUMO: EFEITODA COMPACTAÇÃO SOBRE AATIVIDADE MICROBIANA E TRANSFORMAÇÕES DO CARBONO E NITROGÊENIO EMDOIS LATOSSOLOS COM DISTINTAS MINERALOGIAS
}

\begin{abstract}
A mecanização em atividades agrícolas e florestais tem incrementado a compactação do solo, o que resulta no aumento da densidade e microporosidade, bem como na redução da condutividade hidráulica e das taxas de difusão de $\mathrm{O}_{2}$ e $\mathrm{CO}_{2}$, entre outros efeitos negativos. Assim, a compactação do solo tem o potencial de alterar negativamente a atividade dos seus microrganismos e os processos envolvidos na decomposição da matéria orgânica e ciclagem de nutrientes. Este trabalho foi realizado sob condições controladas para avaliar os efeitos da compactação sobre a atividade microbiana e mineralização do carbono $(C)$ e nitrogênio $(N)$ do solo. Foram utilizados dois Latossolos com distintas mineralogias: um oxídico-gibbsítico (Latossolo Vermelho-Amarelo ácrico - LVA) e um caulinítico (Latossolo Amarelo distrófico LA). Oito tratamentos (níveis de compactação) foram avaliados para cada tipo de solo em um delineamento em blocos casualizados, com seis repetições. A unidade experimental foi composta por anel de PVC com $6 \mathrm{~cm}$ de altura e $4,55 \mathrm{~cm}$ de diâmetro interno, com volume útil de $97,6 \mathrm{~cm}^{3}$. Os anéis de PVC foram preenchidos com uma massa de solo suficiente para alcançar a densidade final de 1,05 e $1,10 \mathrm{~kg} \mathrm{dm}^{-3}$, no LVA e LA, respectivamente. A seguir, as amostras de solo foram umedecidas $\left(0,20 \mathrm{~kg} \mathrm{~kg}^{-1}=80 \%\right.$ da capacidade de campo) e compactadas em uma prensa hidráulica. As pressões de compactação foram de 0, 60, 120, 240, 360, 540, 720 e 900 kPa. Após a compactação dos solos, determinou-se a densidade resultante, por meio do novo volume ocupado pelo solo. Em seguida, cada vaso foi individualmente disposto no interior de um pote plástico de $1 \mathrm{~L}$, que foi hermeticamente fechado. Procedeu-se a uma incubação aeróbia dos solos por um período de 35 dias, e a respiração basal $\left(\mathrm{C}-\mathrm{CO}_{2}\right.$ mineralizado) foi estimada nas duas últimas semanas. Depois do período de incubação, foram realizadas análises químicas e microbiológicas em amostras dos solos: $C$ da biomassa microbiana $\left(C_{M I C}\right), C$ orgânico total $(C O T), N$ total e $\mathrm{N}$ mineral $\left(\mathrm{N}-\mathrm{NH}^{4+}\right.$ e $\left.\mathrm{N}-\mathrm{NO}^{3-}\right)$. Depois disso, foram calculados o $N$ mineral, o $N$ orgânico e a taxa de mineralização líquida de $N$. A compactação ocasionou aumento do $\mathrm{N}_{-} \mathrm{NH}^{4+}$ e da taxa de mineralização líquida de $\mathrm{N}$ nos dois solos e do N-NO ${ }^{3-}$ no LVA; e decréscimo da taxa de perda de COT nos dois solos, de N-NO ${ }^{3-}$ no $L A$, de $C-\mathrm{CO}_{2}$ no LVA e de $C_{M I C}$ em maiores niveis de compactação no LA. Assim, a compactação reduziu a ciclagem de COT provavelmente devido ao aumento da proteção física da matéria orgânica do solo e à menor atividade microbiana. Portanto, é possível concluir que, sob condições controladas, o solo oxídico (LVA) foi mais suscetivel aos efeitos de maiores níveis de compactação do que o caulinítico (LA), considerando a ciclagem de matéria orgânica; e que as pressões de compactação superiores a $540 \mathrm{kPa}$ reduziram o nitrogênio total e orgânico do solo caulinítico (LA), o que foi atribuído às perdas gasosas de $N$.
\end{abstract}

Termos de indexação: densidade do solo, mineralização de carbono, mineralização líquida do nitrogênio, carbono da biomassa microbiana. 


\section{INTRODUCTION}

In recent years there has been a rapid expansion of mechanized silviculture and harvest operation in the forest sector and this has resulted in substantial increases in soil compaction (Wert \& Thomas, 1981; Balbuena et al., 2000; Startsev \& McNabb, 2000; Dias Junior et al., 2008; Silva et al., 2008). Given the short rotation period and high frequency of operations it can undermine the productivity of the stands in a near future, especially in eucalypt plantations.

The negative effects of soil compaction on plant growth have been attributed primarily to the restriction on root growth. However, there is some evidence that soil compaction also alters the size, diversity and activity of the microbial community. As result, there occur changes, for example, in nutrient cycling patterns and their availability to plants (Dick et al., 1988; Jensen et al., 1996a,b; Lee et al., 1996).

It has been shown that soil compaction plays an important role in microbial activity since the increase in soil density leads to altered pore size and distribution, lower $\mathrm{O}_{2}$ and $\mathrm{CO}_{2}$ diffusion rates and greater abundance of anaerobic microsites and consequent reduction in the aerobic microbial activity (Torbert \& Wood, 1992; Jensen et al., 1996a; Tan et al., 2005). These adverse effects of soil compaction on microbial activity seem to result mainly from losses in biopores and other macropores connectivity (Whalley et al., 1995). Low $\mathrm{O}_{2}$ concentration $(<2-5 \%)$ (Parr \& Reuszer, 1962) and low macroporosity $(<10 \%)$ (Linn $\&$ Doran, 1984) cause a reduction in the aerobic microbial activity, and may favor $\mathrm{N}$ losses by denitrification (Breland \& Hansen, 1996; Jensen et al., 1996a; Ruser et al., 2006). Accordingly, soil respiration $\left(\mathrm{CO}_{2}\right.$ production) is a useful indicator of soil organic matter (SOM) decomposition (Hassink, 1994; Lee et al., 1996), by both aerobic and anaerobic microbes, which is a clear advantage over techniques based on $\mathrm{O}_{2}$ uptake.

Despite the fact that the soil compaction may negatively affect the cycling of $\mathrm{C}$ and $\mathrm{N}$ by modifying soil aeration and, or, microbial community structure, there have been a few studies that have dealt with such subject (Torbert \& Wood, 1992; Jensen et al., 1996b; Tan et al., 2005). Under field conditions the microbial biomass $\mathrm{C}\left(\mathrm{C}_{\mathrm{MIC}}\right)$ in the $10-20 \mathrm{~cm}$ soil layer under the tractor track was reduced by $38 \%$ by soil compaction, in comparison to the control soil (Dick et al., 1988). In fact, the authors found a significant negative correlation between $\mathrm{C}_{\mathrm{MIC}}$ and soil density.

The changes in microbial activity and denitrification rates in soils as affected by variations in pore space and moisture levels have been extensively researched (Craswell \& Martin, 1974; Myers et al., 1982; Linn \& Doran, 1984; Rodrigo et al., 1997; Franzluebbers, 1999; Ruser et al., 2006). Nonetheless, few studies have examined the effects of alterations in soil physical properties on $\mathrm{N}$ transformation
(Torbert \& Wood, 1992; Tan et al., 2005; Ruser et al., 2006). Particularly, there is a lack of information about the consequences of soil compaction on $\mathrm{N}$ transformation. Although it seems reasonable to hypothesize that the effects of soil compaction on the microbial community are strong, the few available results indicate the opposite. Linn \& Doran (1984) carried out a study under laboratory conditions and found that microbial activity decreased only slightly under soil compaction. Jensen et al. (1996b) observed that no indicator of microbial biomass was significantly affected when total soil porosity was reduced from 0.60 to $0.51 \mathrm{~m}^{3} \mathrm{~m}^{-3}$ after 21 days of incubation. These findings were attributed to the fact that compaction only altered the larger pores and possibly had no substantial effect on the access of soil microbes to smaller diameter pores.

Under intense heavy machinery traffic soil compaction may be severe. Dias Junior et al. (2008) and Silva et al. (2008) found that, depending on the weight and the number of passes of a loaded forwarder, the soil density may increase to values as high as $32 \%$. Thus, it is likely that not only the soil macropores, but also the micropores are affected by mechanized operations in forest stands so that their impact on soil microbial activity and $\mathrm{C}$ and $\mathrm{N}$ cycling may be more pronounced than previously thought. The recent findings that a major portion of SOM is stabilized in the entrance of small pores in soils (Kaiser \& Guggenberger, 2006) supports this hypothesis. Furthermore, the effects of compaction may be related to soil mineralogy, which influences aggregate type and stability (Silva et al., 2006), and soil minerals differ in their ability to bind and stabilize SOM molecules (Wattel-Koekkoek \& Buurman, 2004; Mikuta et al., 2006).

This study was carried out to evaluate, under controlled conditions, the effects of soil compaction on microbial activity and mineralization of soil $\mathrm{C}$ and $\mathrm{N}$ in two Latosols (Oxisols), one with oxidic-gibbsitic and the other kaolinitic mineralogy.

\section{MATERIAL AND METHODS}

Two Oxisols with different mineralogy, sampled in Santa Maria de Itabira and Santana do Paraíso, in the state of Minas Gerais, were used in the study: a clayey oxidic-gibbsitic Typic Acrustox and a clayey kaolinitic Xantic Haplustox (Latossolo VermelhoAmarelo ácrico - LVA, and Latossolo Amarelo distrófico - LA, respectively, in the Brazilian Soil Classification System). Soil samples were collected in the $0-15 \mathrm{~cm}$ layer under short-rotation eucalypt stands that were seven- and six-year old, respectively. These soil samples were covered and stored under aerobic conditions, initially at the original moisture content at which they had been collected in the field, until the beginning of the experiment a few weeks 
later. They were air-dried, sieved through a $4 \mathrm{~mm}$ mesh and homogenized for subsequent chemical and physical analysis (Table 1).

It is important to remember that the natural structure of soils sieved through $4 \mathrm{~mm}$ mesh is disturbed. However, sieving was necessary for an accurate weighing prior to compression. Nevertheless, visual assessments confirmed that sieving caused only minor change in the natural soil aggregates, since both soils have oxidic aggregates that are highly resistant to defragmentation. Moreover, the small volume of the cylinder may have influenced the results in terms of representativeness offield conditions. However, under controlled conditions, this lab test is useful for understanding the effects of soil compaction on microbial activity, since its implementation under field conditions is difficult.

Eight treatments (compaction levels) were tested for each soil type. Treatments were arranged in a complete block design with six replications. The experimental units consisted of PVC rings (height $6 \mathrm{~cm}$, internal diameter $4.55 \mathrm{~cm}$, volume $97.6 \mathrm{~cm}^{3}$ ). The PVC rings were filled completely with enough soil mass to reach a final density of 1.05 and $1.10 \mathrm{~kg} \mathrm{dm}^{-3}$, respectively, in the LVA and LA. The weighed soils were removed from the PVC rings and moistened with deionized water to increase moisture

Table 1. Chemical and physical properties of the LVA (clayey, oxidic-gibbsitic Oxisol Typic Acrustox,) and the LA (clayey, kaolinitic Oxisol Xantic Haplustox) used in the experiment

\begin{tabular}{|c|c|c|}
\hline Property & LVA & LA \\
\hline TOC $\left(\text { dag kg }^{-1}\right)^{(1)}$ & 2.76 & 2.20 \\
\hline Total-N (dag kg $)^{-1}{ }^{(2)}$ & 0.15 & 0.13 \\
\hline $\mathrm{NH}_{4}^{+}-\mathrm{N}\left(\mathrm{mg} \mathrm{kg}^{-1}\right)^{(3)}$ & 103.61 & 14.51 \\
\hline $\mathrm{NO}_{3}-\mathrm{N}\left(\mathrm{mg} \mathrm{kg}^{-1}\right)^{(4)}$ & 2.28 & 7.87 \\
\hline $\mathrm{pH}^{(5)}$ & 4.5 & 4.8 \\
\hline Field capacity $\left(\mathrm{kg} \mathrm{kg}^{-1}\right)^{(6)}$ & 0.25 & 0.25 \\
\hline Bulk density $\left(\mathrm{kg} \mathrm{dm}^{-3}\right)$ & 1.05 & 1.10 \\
\hline Clay $\left(\mathrm{g} \mathrm{kg}^{-1}\right)^{(7)}$ & 470 & 510 \\
\hline Silt $\left(\mathrm{g} \mathrm{kg}^{-1}\right)^{(7)}$ & 90 & 40 \\
\hline Sand $\left(\mathrm{g} \mathrm{kg}^{-1}\right)^{(7)}$ & 440 & 450 \\
\hline Textural Class & Clay & Clay \\
\hline $\mathrm{SiO}_{2}\left(\mathrm{~g} \mathrm{~kg}^{-1}\right)^{(8)}$ & 71.29 & 135.19 \\
\hline $\mathrm{Al}_{2} \mathrm{O}_{3}\left(\mathrm{~g} \mathrm{~kg}^{-1}\right)^{(8)}$ & 172.93 & 139.99 \\
\hline $\mathrm{Fe}_{2} \mathrm{O}_{3}\left(\mathrm{~g} \mathrm{~kg}^{-1}\right)^{(8)}$ & 60.64 & 44.64 \\
\hline Mineralogy ${ }^{(9)}$ & Oxidic-gibbsitic & Kaolinitic \\
\hline
\end{tabular}

(1) Total Organic Carbon (Yeomans \& Bremner, 1988). ${ }^{(2)}$ Total nitrogen (Bremner \& Mulvaney, 1982). ${ }^{(3)}$ Ammonium nitrogen (Kempers \& Zweers, 1986). (4) Nitrate nitrogen (Yang et al., 1998). ${ }^{(5)} \mathrm{pH}_{\text {water }}, 1: 2,5$ ratio. (10 g soil: $25 \mathrm{~mL} .{ }^{(6)}$ Moisture at field capacity (Ruiz et al., 2003). ${ }^{(7)}$ Particle-size analysis (Embrapa, 1997). ${ }^{(8)}$ Elements in the concentrated sulfuric acid digestion (Embrapa, 1997). ${ }^{(9)}$ x-ray diffraction (Embrapa, 1997). to $80 \%$ of field capacity $\left(0.20 \mathrm{~kg} \mathrm{~kg}^{-1}\right)$; then, they were filled back into the PVC rings and subjected to increasing compaction in a hydraulic press equipped with a dynamometer. The compaction pressures applied to the soils were 0 (control), 60, 120, 240, 360, 540,720 , and $900 \mathrm{kPa}$. After compression, the new soil bulk density was calculated based on the new soil volume.

Subsequently, the PVC rings with the moist compacted soils were dried down in a forced air chamber at room temperature to reduce soil moisture to $56 \%$ of the field capacity. Then, each PVC ring was placed in a separate 1 L-polyethylene pot that was hermetically closed. The PVC rings were incubated under aerobic conditions in these pots for 21 days. During this period, the pots were opened for 10 min once a week to allow air exchange. At these occasions the amount of water lost by the soils through evaporation, calculated by means of weighing, was reapplied to the soil surface, infiltrating later. After 21 days, when microbial activity had stabilized, the basal soil respiration was determined once a week during the following two weeks using a $1 \mathrm{~mol} \mathrm{~L}^{-1}$ $\mathrm{NaOH}$-trap to capture the $\mathrm{C}-\mathrm{CO}_{2}$ respired. The excess $\mathrm{NaOH}$ was titrated with $\mathrm{HCl}$ after precipitation of carbonate with $\mathrm{BaCl}_{2}$ (Anderson, 1982). An important aspect to consider is whether the weekly frequency of opening the pots during the incubation period was sufficient for the soil aeration system, which may have become partially anaerobic, changing the dynamics of carbon and nitrogen. Thus, this fact should be considered when interpreting results, especially those related to the reduction of soil aeration due to soil compaction.

Following this incubation period, soil chemical and microbiological properties were determined immediately after the end of the experiment. The microbial biomass $\mathrm{C}\left(\mathrm{C}_{\mathrm{MIC}}\right)$ was evaluated based on the irradiation-extraction procedure (Islam \& Weil, 1998). The extractant used was $0.5 \mathrm{~mol} \mathrm{~L}^{-1} \mathrm{~K}_{2} \mathrm{SO}_{4}$ $(10 \mathrm{~g}$ soil: $30 \mathrm{~mL})$ and the $\mathrm{C}$ in the extracts was quantified by wet oxidation in acid media (Yeomans $\&$ Bremner, 1988). A $K_{C}$ value of 0.45 was adopted (Balota et al., 1998). The soil total organic carbon (TOC) was determined by wet oxidation with dichromate (Yeomans \& Bremner, 1988). The TOC content at the end of the experiment (TOC final) was subtracted from that at the beginning (TOC initial), divided by the initial TOC and multiplied by 100 in order to obtain the relative amount of TOC lost during the incubation period (from the $1^{\text {st }}$ to the $35^{\text {th }}$ day).

Additionally, the following forms of nitrogen $(\mathrm{N})$ were determined: total $\mathrm{N}, \mathrm{NH}_{4}-\mathrm{N}, \mathrm{NO}_{3}-\mathrm{N}$, and mineral- $\mathrm{N}\left(\mathrm{NH}_{4}-\mathrm{N}+\mathrm{NO}_{3}-\mathrm{N}\right)$. Total-N was determined by sulfuric acid digestion and Kjeldahl distillation (Bremner \& Mulvaney, 1982). Mineral-N was extracted with $\mathrm{KCl} 1 \mathrm{~mol} \mathrm{~L}^{-1}(10 \mathrm{~g}$ soil : $50 \mathrm{~mL}$ extractant) during $10 \mathrm{~min}$ and the concentration of $\mathrm{NO}_{3}-\mathrm{N}$ (Yang et al., 1998) and $\left(\mathrm{NH}_{4}-\mathrm{N}\right)($ Kempers \& 
Zweers, 1986) were determined colorimetrically. The net nitrogen mineralization $\left(\mu \mathrm{g} \mathrm{g}^{-1}\right.$ day $\left.^{-1}\right)$ corresponds to the amount of mineral $\mathrm{N}$ gained during the incubation period. Finally the organic-N was estimated by the difference, based on: [total-N mineral-N].

The data for each soil type (LVA and LA), individually, were subjected to Analysis of Variance (ANOVA) and regression, using software SAEG (Euclydes, 1997). The coefficients of the adjusted equations were assessed by the $\mathrm{F}$-test (at significance levels of $0.1,1$ and $5 \%$ ) considering the mean square error of ANOVA of the experiment. Finally, among two or more models with statistically significant coefficients, the one with the higher determination coefficient $\left(\mathrm{R}^{2}\right)$ was chosen.

\section{RESULTS AND DISCUSSION}

Soil density increased up to 22.8 and $21.8 \%$ in the clayey oxidic-gibsitic Oxisol Typic Acrustox (LVA) and in the clayey kaolinitic Oxisol Xantic Haplustox (LA), respectively, in response to the compression applied (Figure 1a). Although the density curves were virtually parallel for both soils, the effect of compaction on soil respiration was very distinct. The $\mathrm{C}-\mathrm{CO}_{2}$ evolution during the two-week incubation period was greater in the LVA than in the LA under absence of compaction, but it was significantly reduced (20\%) as compaction pressure increased up to $500 \mathrm{kPa}$ (soil density around $1.2 \mathrm{~kg} \mathrm{dm}^{-3}$ ) (Figure 1b). In the LVA, the effect of soil compaction on the reduction of $\mathrm{C}_{-} \mathrm{CO}_{2}$ evolution was probably due to increased physical protection of soil organic matter (SOM) and also to a decrease of soil porosity and the consequent reduction of soil aeration, which are effects that could not be isolated in this study. Torbert \& Wood (1992) also observed a $65 \%$ reduction in soil respiration when soil density was increased. This effect was more pronounced than in the current study since soil compaction in their study was much greater (increased from 1.4 to $1.8 \mathrm{~kg} \mathrm{dm}^{-3}$ ). On the other hand, in the LA there was no significant effect of increasing soil compaction on $\mathrm{C}-\mathrm{CO}_{2}$ evolution (Figure $1 \mathrm{~b}$ ). No conclusive explanation for the greater resilience of the LA in relation to $\mathrm{C}-\mathrm{CO}_{2}$ evolution from soil compaction can be given, but it is possible that the more labile $\mathrm{C}$ sources might have been mineralized during the preincubation period (day 1 to 21 ) at a greater proportion than in the LVA. The optimum moisture and temperature conditions during the incubation period may have favored microbial activity and, consequently, labile $\mathrm{C}$ sources were rapidly mineralized. In fact, C$\mathrm{CO}_{2}$ evolution from incubated soil samples is greater in the first couple of weeks (Araújo et al., 2001), and the more abundant $\mathrm{Fe}$ and $\mathrm{Al}$ oxides may have favored SOM stabilization (Spielvogel et al., 2008) to a greater extent in the LVA than the kaolinitic LA.

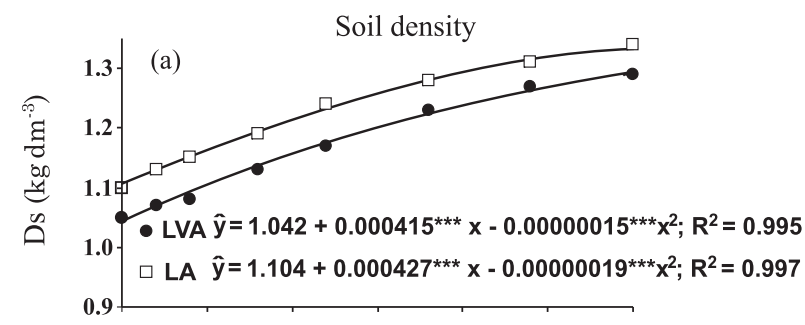

(b)

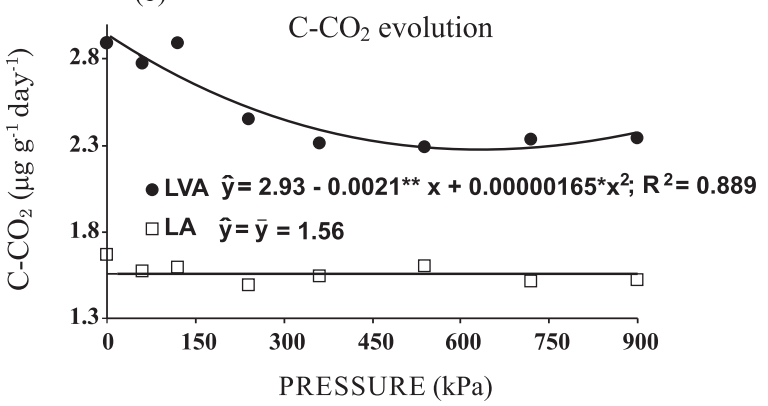

Figure 1. Soil density (a), and $\mathrm{C}-\mathrm{CO}_{2}$ evolution (b) from two Oxisols subjected to increasing compaction pressures. (***, **, *: significance of the coefficients by the F-test, respectively, at the level of $0.1,1$ and $5 \%$ ).

The soil total organic carbon (TOC) concentration, at the end of 35 day-incubation period, was increased linearly by the compaction pressure applied to both soils (Figure 2a). A reverse trend was observed for the rate of TOC lost through mineralization during the same period (Figure 2b). The smaller soil organic matter (SOM) mineralization in response to increased compaction can be attributed to greater physical protection of SOM. Breland \& Hansen (1996) reported that compaction reduced total porosity and altered pore size distribution, favoring the contribution of smaller pores, which could physically protect organic materials from microbial degradation. In compacted soils the smaller pore size obstructs soil solution movement and aeration and thus the activity of decomposing organisms. Research results indicate that organic compounds that are sorbed to the entrance of small pores are resistant to chemical oxidation and will possibly resist biodegradation by enzymes of decomposing microbes (Kaiser \& Guggenberger, 2006).

During the relatively short incubation period (35 days) there was high TOC losses (Figure 2b), especially in soils subjected to low compaction pressures (8.0 and $7.7 \%$, respectively, in the LVA and LA subjected to $60 \mathrm{kPa}$ pressure), but it was reduced when compaction pressures were increased.

The $\mathrm{C}$ content in the microbial biomass $\left(\mathrm{C}_{\mathrm{MIC}}\right)$ showed a quadratic response to the increasing compaction pressures (Figure 3 ). The highest $\mathrm{C}_{\text {MIC }}$ values were 20 and $18 \mu \mathrm{g} \mathrm{g}^{-1}$ observed at the pressures 240 and $120 \mathrm{kPa}$, respectively, in the LVA and LA. 

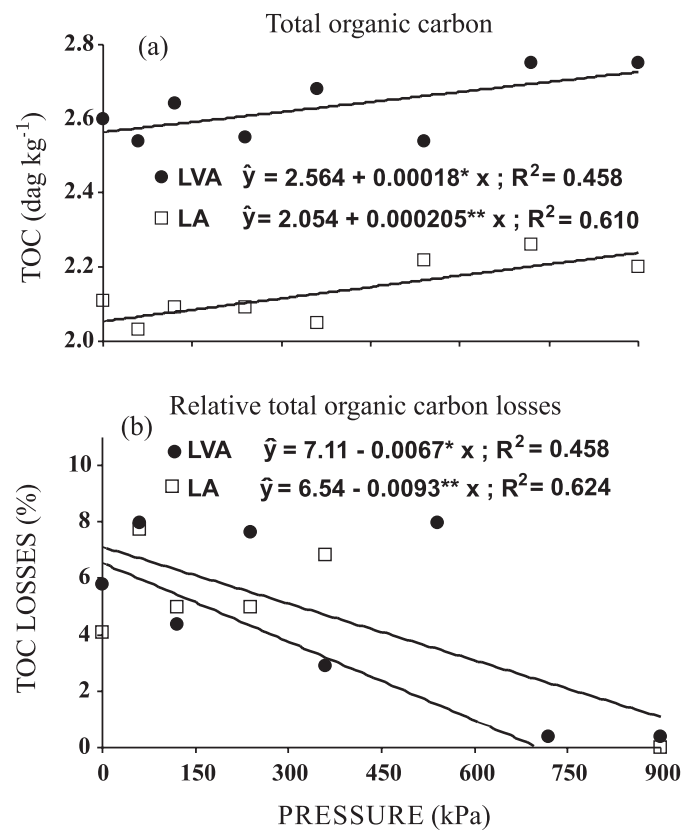

Figure 2. Total organic carbon (TOC) concentration (a) and relative TOC losses (b) of two Oxisols during the 35 day-incubation period as related to compaction pressures. (***, **, *: significance of the coefficients by the F-test, respectively, at the level of $0.1,1$ and $5 \%$ ).

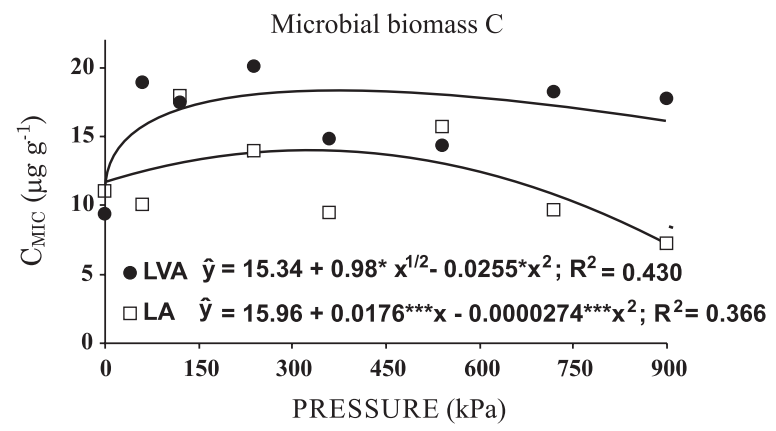

Figure 3. Microbial biomass $\mathbf{C}$ concentration in two Oxisols subjected to increasing compaction pressures. (***, **,*: significance of the coefficients by the F-test, respectively, at the level of $0.1,1$ and $5 \%$ ).

The closer contact between SOM with soil microorganisms under low to intermediate compaction pressures may have created more favorable conditions and, or, microsites for microbial growth. However, a substantial drop in the $\mathrm{C}_{\mathrm{MIC}}$ (to a value of $7.2 \mu \mathrm{g} \mathrm{g}^{-1}$ ) was observed when compaction pressure in the LA reached $900 \mathrm{kPa}$. This effect may have resulted from the unfavorable conditions for microbial growth under high soil compaction, as well as greater physical protection of SOM stabilized at the entrance of micropores, as discussed above. The lower response of $\mathrm{C}_{\mathrm{MIC}}$ in the LVA (Figure 3 ) may reflect its oxidic mineralogy. In oxidic soils, especially Oxisols, microaggregation is stronger, which enables them to resist higher compaction pressures. Also, it has been recently shown that aggregation and organic $\mathrm{C}$ stabilization depend strongly on soil mineralogy (Paul et al., 2008). This is further supported by results of a field study where the $\mathrm{C}_{\mathrm{MIC}}$ of a sandy-loam soil was not altered by tractor traffic, possibly because the porous space was not reduced enough to affect the microbial population (Lee et al., 1996).

In both soils, exchangeable ammonium-N $\left(\mathrm{NH}_{4}{ }^{+}-\right.$ N) was several times higher than nitrate- $\mathrm{N}\left(\mathrm{NO}_{3}^{-}-\right.$ $\mathrm{N})$, and about six time greater in the LVA than in the LA (Figure 4a,b). Conversely, $\mathrm{NO}_{3}-\mathrm{N}$ was about four times greater in the LA than in the LVA, resulting in a much higher $\mathrm{NH}_{4}{ }^{+}-\mathrm{N}: \mathrm{NO}_{3}-\mathrm{N}$ ratio in the $\mathrm{LVA}$. Ammonium-N showed a quadratic response to soil compaction in the LVA, whereas the response pattern was linear in the LA (Figure 4a). The highest increments observed for $\mathrm{NH}_{4}{ }^{+}-\mathrm{N}$ were 11.8 and $16.6 \%$ at 240 and $900 \mathrm{kPa}$, respectively, in the LVA and LA. Ammonium-N accumulation may be a result of anaerobic conditions caused by soil compaction, which can lead to $\mathrm{NO}_{3}^{-}-\mathrm{N}$ conversion by denitrifiers, although much of the $\mathrm{NH}_{4}{ }^{+}-\mathrm{N}$ may have been formed by anaerobic decomposition of soil organic N (Abbasi \& Adams, 1999).

Depending on the soil type, compaction had opposite effects on the $\mathrm{NO}_{3}-\mathrm{N}$ content. Maximum compression $(900 \mathrm{kPa})$ resulted in a $28.6 \%$ increment in $\mathrm{NO}_{3}-\mathrm{N}$ in the $\mathrm{LVA}$ and a $6.3 \%$ reduction in the LA (Figure 4b). The observed decrease in $\mathrm{NO}_{3}-\mathrm{N}$ in the kaolinitic LA could be due to gaseous $\mathrm{N}$ losses through denitrification occurring in anaerobic
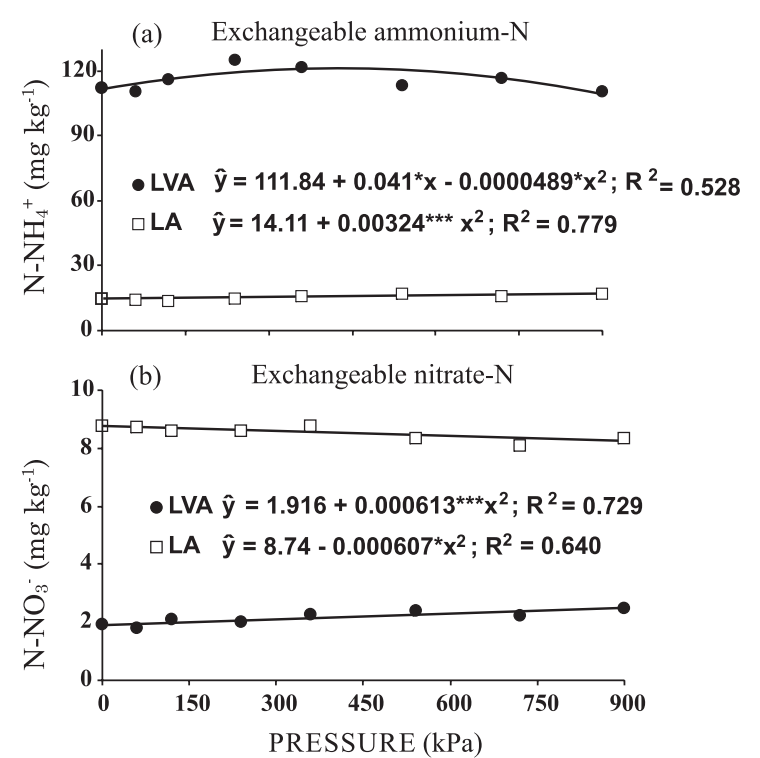

Figure 4. Exchangeable ammonium-N (a), and nitrate-N (b), in two Oxisols subjected to increasing compaction pressures. (***, **, *: significance of the coefficients by the F-test, respectively, at the level of $0.1,1$ and $5 \%$ ). 
microsites resulting from compaction, where microbial $\mathrm{O}_{2}$ demand exceeds its supply by diffusion and prevents aerobic nitrification (Arah \& Smith, 1989; Adams \& Akhtar, 1994). These gaseous losses of $\mathrm{NO}_{3}$. -N supposing had occured in LA only at higher levels of soil compaction, can be corroborated by corresponding decreases of organic N, at the same compaction levels (Figure 6b). In more oxidic and strongly aggregated LVA the effect of compaction was less severe and the increment in $\mathrm{NO}_{3}-\mathrm{N}$ suggests that even under high compression there were still microsites under aerobic conditions that supported aerobic nitrification.

Soil mineral nitrogen $\left(\mathrm{N}_{\mathrm{MIN}}=\mathrm{NO}_{3}{ }^{-}-\mathrm{N}+\mathrm{NH}_{4}{ }^{+}-\mathrm{N}\right)$ showed a quadratic response to compaction in the LVA and a linear increment in the LA (Figure 5a). The greatest increments reached 11.7 and $8.5 \%$ at pressures of 240 and $900 \mathrm{kPa}$ in the LVA and LA, respectively. The average $\mathrm{N}_{\mathrm{MIN}}$ concentration was 4.95 times larger in the LVA than in the LA. In the LVA not only $\mathrm{N}_{\mathrm{MIN}}$ availability was greater, but also the $\mathrm{NH}_{4}{ }^{+}-\mathrm{N}: \mathrm{NO}_{3}-\mathrm{N}$ ratio, which may be favorable for eucalypt growth in view of its preference for $\mathrm{NH}_{4}{ }^{+}-\mathrm{N}$ over $\mathrm{NO}_{3}-\mathrm{N}$ (Locatelli et al., 1984).

Net $\mathrm{N}$ mineralization rates in the LVA were on average 8.3 times higher than in the LA. The response to soil compaction was greater in the LVA than in the LA, with a quadratic pattern in the former to LVA and a positive linear pattern in the last one (Figure 5b). Nitrogen net mineralization was greater at intermediate compaction pressures, and

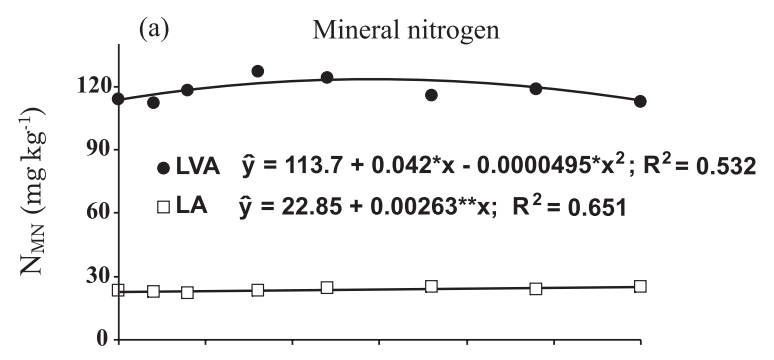

(b) Nitrogen mineralization rate

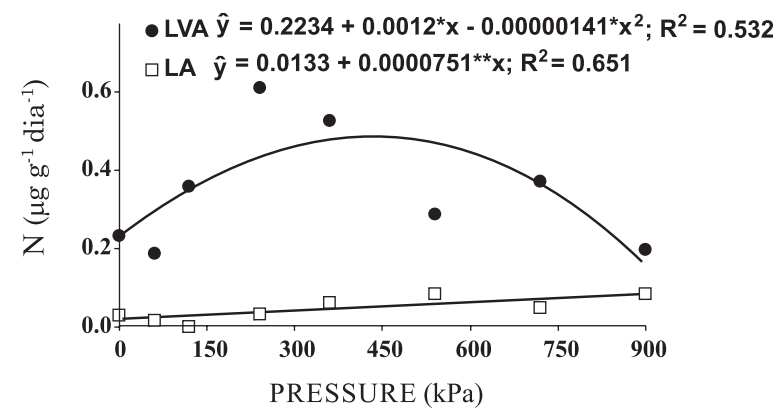

Figure 5. Mineral nitrogen (ammonium-N + nitrateN) (a) and nitrogen mineralization rate (b) in two Oxisols subjected to increasing compaction pressures. $(* * *, * *, *$ : significance of the coefficients by the F-test, respectively, at the level of $0.1,1$ and $5 \%$ ). subsequently declined to lower values at higher pressures in the LVA. Although under high compression levels the established anaerobic conditions led to a greater reduction in $\mathrm{N}$ mineralization in the LVA, they still were greater than in the LA. These inequalities reflect differences not only in the SOM content, but also SOM quality and soil aeration (Broersma et al., 1996).

The response patterns of the two soil types in $\mathrm{C}$ and $\mathrm{N}$ mineralization as related to soil compaction were distinct (Figures $2 \mathrm{~b}$ and $5 \mathrm{~b}$ ). Jensen et al. (1996b) attributed this difference to changes in denitrification as a response to less abundant macropores, and thus less aeration due to compaction.

Soil compaction showed no effect on total $\mathrm{N}$ and organic $\mathrm{N}$ in the LVA, but there was a quadratic response in the LA (Figure 6a,b). According to Hassink et al. (1993) and Breland (1994), N mineralization is more affected by physical protection than $\mathrm{C}$ mineralization. However, in the LA Oxisol, pressures above $540 \mathrm{kPa}$ led to a decrease in organic $\mathrm{N}$, suggesting that gaseous $\mathrm{N}$ losses through denitrification were favored under higher soil densities. In fact, a $286 \%$ increase in loss of original soil $\mathrm{N}$ was observed by Torbert \& Wood (1992) when soil density was increased from 1.4 to $1.8 \mathrm{~kg} \mathrm{dm}^{-3}$, a result attributed to gaseous $\mathrm{N}$ losses through denitrification by anaerobic microorganisms.

The fitted curves of total and organic nitrogen were very similar because organic $\mathrm{N}$ represents, on average, 93 and $98 \%$ of total $\mathrm{N}$, respectively, in the LVA and LA (Figure 6).

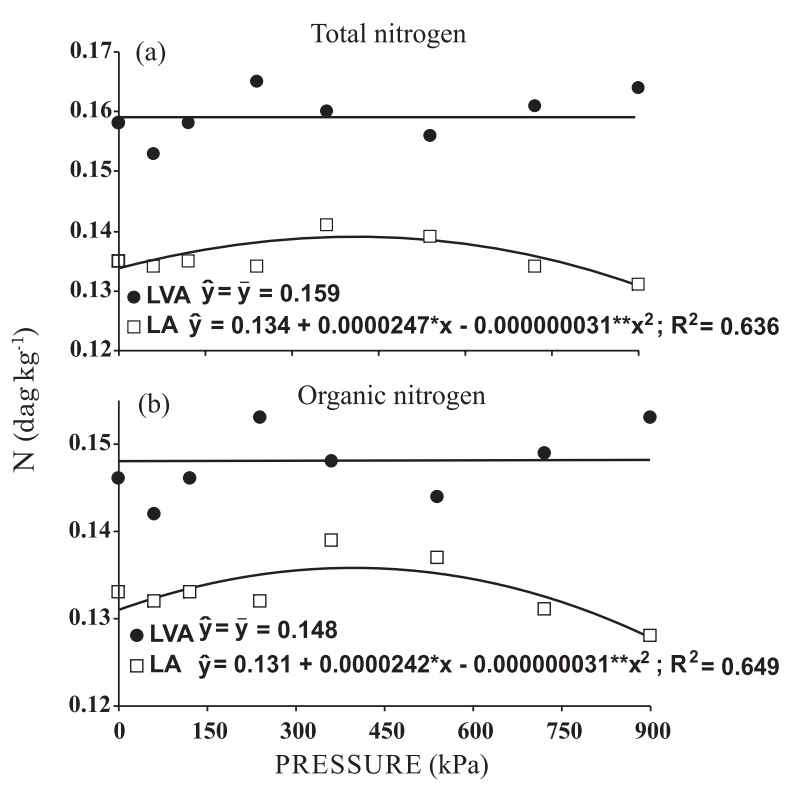

Figure 6. Total (a) and organic nitrogen (b) in two Oxisols subjected to increasing compaction pressures. $(* * *, * *, *$ : significance of the coefficients by the F-test, respectively, at the level of $0.1,1$ and $5 \%$ ). 


\section{CONCLUSIONS}

1. Under controlled conditions, organic matter cycling in the the oxidic-gibbsitic Oxisol (LVA) was more susceptible to the effects of high compaction than in the kaolinitic Oxisol (LA).

2. In this study, compaction pressures above $540 \mathrm{kPa}$ reduced total and organic nitrogen in the kaolinitic soil (LA), which was attributed to gaseous N losses.

\section{LITERATURE CITED}

ABBASI, M.K. \& ADAMS, W.A. Assessment of the contribution of denitrification to $\mathrm{N}$ losses from compacted grassland soil by $\mathrm{NO}_{3}$ - disappearance and $\mathrm{N}_{2} \mathrm{O}$ production during anaerobic incubation. Canadian J. Soil Sci., 79:57-64, 1999.

ADAMS, W.A. \& AKHTAR, N. The possible consequences for herbage growth of waterlogging compacted pasture soils. Plant Soil, 162:1-17, 1994.

ANDERSON, J.P.E. Soil respiration. In: PAGE, A.L.; MILLER, R.H. \& KEENEY, D.R., eds. Methods of soil analysis. 2.ed. Madison, American Society of Agronomy/Soil Science Society of America, 1982. Part 2. p.831-871.

ARAH, J.R.M. \& SMITH, K.A. Steady-state denitrification in aggregated soils: A mathematical model. J. Soil Sci., 40:139149, 1989.

ARAÚJO, A.M.S.; SAMPAIO, E.V.S.B. \& SALCEDO, I.H. Mineralização do $\mathrm{C}$ e do $\mathrm{N}$ em amostras armazenadas de solo cultivado com cana-de-açúcar, ao longo de dez anos, com e sem fertilização nitrogenada. R. Bras. Ci. Solo, 25:43-53, 2001.

BALBUENA, R.H.; TERMINIELLO, A.M.; CLAVERIE, J.A.; CASADO, J.P. \& MARLATS, R. Compactación del suelo durante la cosecha forestal. Evolución de las propriedades físicas. R. Bras. Eng. Agric. Amb., 4:453-459, 2000.

BALOTA, E.L.; COLOZZI-FILHO, A.; ANDRADE, D.S. \& HUNGRIA, M. Biomassa microbiana e sua atividade em solos sob diferentes sistemas de preparo e sucessão de culturas. R. Bras. Ci. Solo, 22:641-650, 1998.

BRELAND, T.A. Enhanced mineralization and denitrification as a result of heterogeneous distribution of clover residues in soil. Plant Soil, 166:1-12, 1994.

BRELAND, T.A. \& HANSEN, S. Nitrogen mineralization and microbial biomass as affected by soil compaction. Soil Biol. Biochem., 28:655-663, 1996.

BREMNER, J.M. \& MULVANEY, C.S. Nitrogen - Total. In: PAGE, A.L.; MILLER, R.H. \& KEENEY, D.R., eds. Methods of soil analysis. 2.ed. Madison, American Society of Agronomy/Soil Science Society of America, 1982. Part 2. p.595-624.

BROERSMA, K.; JUMA, N.G. \& ROBERTSON, J.A. Net nitrogen mineralization from a Gray Luvisol under diverse cropping systems in the Peace River region of Alberta. Canadian J. Soil Sci., 76:117-123, 1996.
CRASWELL, E.T. \& MARTIN, A.E. Effects of moisture content on denitrification in clay soil. Soil Biol. Biochem, 6:127129,1974

DIAS JUNIOR, M.S.; SILVA, S.R.; SANTOS, N.S. \& ARAUJO JUNIOR, C.F. Assessment of the soil compaction of two Ultisols caused by logging operations. R. Bras. Ci. Solo, 32:2245-2253, 2008.

DICK, R.P.; MYROLD, D.D. \& KERLE, E.A. Microbial biomass and soil enzyme activities in compacted and rehabilitated skid trail soil. Soil Sci. Soc. Am. J., 52:512-516, 1988.

EMPRESA BRASILEIRA DE PESQUISA AGROPECUÁRIA EMBRAPA. Centro Nacional de Pesquisa de Solos. Manual de métodos de análise de solo. 2.ed. Rio de Janeiro, 1997. 212p.

EUCLYDES, R.F. Manual de utilização do programa SAEG (Sistema para Análises Estatísticas e Genéticas). Viçosa, MG, Universidade Federal de Viçosa, 1997. 150p.

FRANZLUEBBERS, A.J. Microbial activity in response to water-filled pore space of variably eroded southern Piedmont soils. Appl. Soil Ecol., 11:91-101, 1999.

HASSINK, J.; BOUWMAN, L.A.; ZWART, K.B. \& BRUSSAARD, L. Relationship between habitable pore space, soil biota and mineralization rates in grassland soils. Soil Biol. Biochem., 25:47-55, 1993.

HASSINK, J. Effects of soil texture and grassland management on soil organic $\mathrm{C}$ and $\mathrm{N}$ and rates of $\mathrm{C}$ and N mineralization. Soil Biol. Biochem., 26:1221-1231, 1994.

ISLAM, K.R. \& WEIL, R.R. Microwave irradiation of soil for routine measurement of microbial biomass carbon. Biol. Fert. Soils, 27:408-416, 1998.

JENSEN, L.S.; MCQUEEN, D.J. \& SHEPHERD, T.G. Effects of compaction on N-mineralization and microbial-C and N. I. Field measurements. Soil Tillage Res., 38:175-188, 1996a.

JENSEN, L.S.; McQUEEN, D.J.; ROSS, D.J. \& TATE, K.R. Effects of soil compaction on N-mineralization and microbial-C and -N. II. Laboratory simulation. Soil Tillage Res., 38:189-202, 1996b.

KAISER, K. \& GUGGENBERGER, G. Sorptive stabilization of organic matter by microporous goethite: sorption into small pores vs. surface complexation. Eur. J. Soil Sci., 58:45-59, 2006.

KEMPERS, A.J. \& ZWEERS, A. Ammonium determination in soil extracts by the salicylate method. Comm. Soil Sci. Plant Anal., 17:715-723, 1986.

LEE, W.J.; WOOD, C.W.; REEVES, D.W.; ENTRY, J.A. \& RAPER, R.L. Interactive effects of wheel-traffic and tillage system on soil carbon and nitrogen. Comm. Soil Sci. Plant Anal., 27:3027-3043, 1996.

LINN, D.M. \& DORAN, J.W. Effects of water-filled pore space on carbon dioxide and nitrous oxide production in tilled and nontilled soils. Soil Sci. Soc. Am. J., 48:1267-1272, 1984.

LOCATELLI, M.; BARROS, N.F.; NEVES, J.C.L. \& NOVAIS, R.F. Efeito de formas de nitrogênio sobre o crescimento e composição mineral de mudas de eucalipto. R. Árvore, 8:53-69, 1984 
MIKUTTA, R.; KLEBER, M.; TORN, M.S. \& JAHN, R. Stabilization of soil organic matter: Association with minerals or chemical recalcitrance? Biogeochemistry, $77: 25-56,2006$

MYERS, R.J.K.; CAMPBELL, C.A. \& WEIER, K.L. Quantitative relationship between net nitrogen mineralization and moisture content of soils. Canadian J. Soil Sci., 62:111-114, 1982.

PARR, J.F. \& REUSZER, H.W. Organic matter decomposition as influenced by oxygen level and flow rate of gases in the constant aeration method. Soil Sci. Am. Proc., 26:552556,1962

PAUL, S.; FLESSA, H.; VELDKAMP, E. \& LÓPEZ-ULLOA, M. Stabilization of recent soil carbon in the humid tropics following land use changes: evidence from aggregate fractionation and stable isotope analyses. Biogeochem., 87:247-263, 2008.

RODRIGO, A.; RECOUS, S.; NEEL, C. \& MARY, B. Modelling temperature and moisture effects on $\mathrm{C}-\mathrm{N}$ transformations in soils: comparison of nine models. Ecol. Model., 102:325-339, 1997.

RUIZ, H.A.; FERREIRA, G.B. \& PEREIRA, J.B.M. Estimativa da capacidade de campo de latossolos e neossolos quartzarênicos pela determinação do equivalente de umidade. R. Bras. Ci. Solo, 27:389-393, 2003.

RUSER, R.; FLESSA, H.; RUSSOW, R.; SCHMIDT, G.; BUEGGER, F. \& MUNCH, J.C. Emission of $\mathrm{N}_{2} \mathrm{O}, \mathrm{N}_{2}$ and $\mathrm{CO}_{2}$ from soil fertilized with nitrate: effect of compaction, soil moisture and rewetting. Soil Biol. Biochem., 38:263$274,2006$.

SILVA, S.R.; BARROS, N.F. \& COSTA, L.M. Atributos físicos de dois Latossolos afetados pela compactação do solo. R. Bras. Eng. Agric. Amb., 10:842-847, 2006.

SILVA, S.R.; BARROS, N.F.; COSTA, L.M. \& LEITE, F.P. Soil compaction and eucalyptus growth in response to forwarder traffic intensity and load. R. Bras. Ci. Solo, 32:921-932, 2008.
SPIELVOGEL, S.; PRIETZEL, J. \& KÖGEL-KNABNER, I. Soil organic matter stabilization in acidic forest soils is preferential and soil type-specific. Eur. J. Soil Sci., 59:674692,2008

STARTSEV, A.D. \& McNABB, D.H. Effects of skidding on forest soil infiltration in west-central Alberta. Canadian J. Soil Sci., 80:617-624, 2000.

TAN, X.; CHANG, S.X. \& KABZEMS, R. Effects of soil compaction and forest floor removal on soil microbial properties and $\mathrm{N}$ transformations in a boreal forest longterm soil productivity study. For. Ecol. Manag., 217:158170,2005 .

TORBERT, H.A. \& WOOD, C.W. Effects of soil compaction and water-filled pore space on soil microbial activity and N losses. Comm. Soil Sci. Plant Anal., 23:1321-1331, 1992.

WATTEL-KOEKKOEK, E.J.W. \& BUURMAN, P. Mean residence time of kaolinite and smectite-bound organic matter in mozambiquan soils. Soil Sci. Soc. Am. J., 68:154161,2004

WERT, S. \& THOMAS, B.R. Effects of skid roads on diameter, height, and volume growth in Douglas-fir. Soil Sci. Soc. Am. J., 45:629-632, 1981.

WHALLEY, W.R.; DUMITRU, E. \& DEXTER, A.R. Biological effects of soil compaction. Soil Tillage Res., 35:53-68, 1995.

YANG, J.E.; SKOGLEY, E.O.; SCHAFF, B.E. \& KIM, J.J. A simple spectrophotometric determination of nitrate in water, resin, and soil extracts. Soil Sci. Soc. Am. J., 62:1108$1115,1998$.

YEOMANS, J.C. \& BREMNER, J.M. A rapid and precise method for routine determination of organic carbon in soil. Comm. Soil Sci. Plant Anal., 19:1467-1476, 1988. 
